\title{
In Memoriam: Sven-Olof Olofsson (1947-2011) ${ }^{1}$
}

\author{
Jan Borén, ${ }^{2}$ Göran Bondjers, and Olov Wiklund \\ Department of Molecular and Clinical Medicine/Wallenberg Laboratory, Sahlgrenska Academy at the \\ University of Gothenburg, Gothenburg, Sweden
}

Sven-Olof Olofsson has died suddenly and unexpectedly at the age of 64. After graduating from high school, he studied medicine at the medical faculty in Gothenburg the faculty to which he remained faithful for the rest of his life. While still a medical student, he began his doctoral work at the Department of Medical and Physiological Chemistry, and in 1975, he defended his thesis on high-density lipoprotein metabolism. In parallel, he completed his medical studies and became a licensed physician in 1973 .

After a couple of years as a visiting researcher in the US in the laboratory of Petar Alaupovic at the Oklahoma Medical Research Foundation, Sven-Olof returned to the Department of Medical and Physiological Chemistry at the University of Gothenburg, where he became a professor in 1994. He combined his research role with clinical practice and participated in both clinical and preclinical research. It was therefore a natural transition when, in 2005, he transferred his research to the Wallenberg Laboratory for Cardiovascular Research at Sahlgrenska University Hospital. At the time of his death, Sven-Olof led a large research team and was a valued and frequently invited speaker at international scientific congresses. His contagious passion for science attracted many $\mathrm{PhD}$ students, and he was always generous with his time for scientific guidance. During his career, Sven-Olof supervised 17 doctoral students who have successfully defended their theses, and many Swedish and international young scientists have worked in his laboratory.

Although Sven-Olof had much involvement in the Medical Faculty of the University of Gothenburg, his main passion was research. His publication list reads like a history book that shows how medical and biochemical research has developed over 40 years: from classical biochemical methods to molecular biology, genetics and cell biology, and always at the forefront of the field. He is most renowned for his studies on the assembly and secretion of apolipoprotein (apo)B100-containing very low density lipoproteins (VLDL). Despite its clinical importance, the understanding of the biosynthesis of VLDL was for many years an enigma to scientists, mainly because of the large size and insolubility of apoB100. To further our understanding of the synthesis and intracellular transport of apoB100, Sven-Olof's laboratory performed kinetic studies using pulse-chase methodology

DOI 10.1194/jlr.E030486

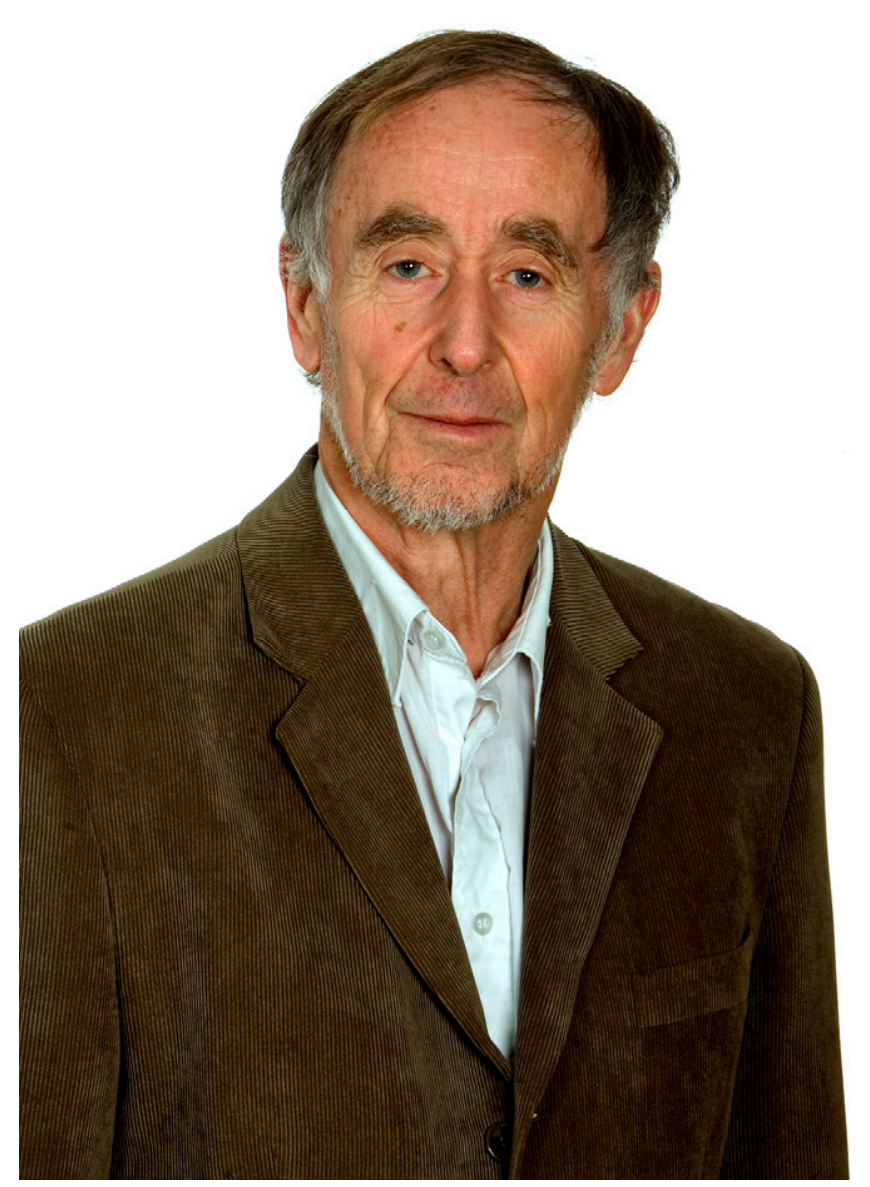

with ${ }^{35}$ S-methionine in the human hepatocyte cell line HepG2 (1-3). These kinetic studies indicated that the rate-limiting step in the secretion of apoB100 was the transfer of apoB100 from the endoplasmic reticulum (ER) membrane-associated pool to apoB100-containing lipoproteins in the ER lumen (2-4). However, the rate of disappearance of apoB100 from the ER membrane was much higher than the rate of apoB100 secretion. This discrepancy was initially difficult to understand and Sven-Olof designed numerous control experiments to rule out methodological recovery problems as the explanation. However, the only explanation for the

\footnotetext{
${ }^{1}$ This tribute also appears in Atherosclerosis.

${ }^{2}$ To whom correspondence should be addressed. e-mail: Jan.Boren@wlab.gu.se
} 
discrepancy was that a portion of the intracellular pool of apoB100 diverged from the secretory process to undergo posttranslational degradation (2). This was the first evidence that posttranslational degradation regulates apoB secretion. Sven-Olof continued to elucidate the assembly of apoB100containing lipoproteins in detail and showed that the assembly of $\mathrm{VLDL}_{1}$ requires several steps: the formation of preVLDL, its conversion to $\mathrm{VLDL}_{2}$, and a transfer to the Golgi apparatus where the major proportion of triglycerides is added (5). This explained the time delay between the biosynthesis of apoB100 and the major addition of lipids to the $\mathrm{VLDL}_{1}$ particle (estimated to be approximately $15 \mathrm{~min}$ ). Sven-Olof and coworkers later confirmed the presence of such a time delay by turnover studies in humans (6).

In recent years, Sven-Olof performed groundbreaking research on how dysfunctional regulation of lipid storage in cytosolic lipid droplets may play a key role in lipidinduced inflammation and the development of insulin resistance. In particular, he identified the SNARE ( Soluble

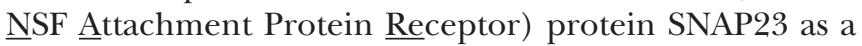
novel link between lipid accumulation and insulin resistance $(7,8)$.

In parallel with his research efforts, Sven-Olof worked for many years at the hospital's cardiology department, where he transferred the knowledge acquired in his basic research to treat patients with lipid disorders. As a physician, he was very popular among his patients. Despite his highly specialized knowledge, he retained a holistic perspective of mankind when meeting patients.

Sven-Olof was a highly regarded, respected, and muchloved colleague: always enthusiastic and full of ideas, always wise and compassionate, but also with high standards-not least for himself. In terms of quality of research, he was incorruptible and never sought any shortcuts. His door was always open to colleagues and young researchers who sought advice and support, and any meetings often ended with his chuckling laugh. Outside work, he devoted himself to his family and to sailing, especially during summers spent in the archipelago and in the family's summer house on Klåverön.

We have lost one of our foremost scholars and teachers, but above all, a close and dear friend. His memory will stand as a figure of very important stature in the field of lipidology.

\section{REFERENCES}

1. Wettesten, M., K. Bostrom, G. Bondjers, M. Jarfeldt, P. I. Norfeldt, M. Carrella, O. Wiklund, J. Borén, and S. O. Olofsson. 1985. Pulsechase studies of the synthesis of apolipoprotein B in a human hepatoma cell line, Hep G2. Eur. J. Biochem. 149: 461-466.

2. Boström, K., M. Wettesten, J. Borén, G. Bondjers, O. Wiklund, and S-O. Olofsson. 1986. Pulse-chase studies of the synthesis and intracellular transport of apolipoprotein B-100 in Hep G2 cells. J. Biol. Chem. 261: 13800-13806.

3. Boström, K., J. Borén, M. Wettesten, A. Sjöberg, G. Bondjers, O. Wiklund, P. Carlsson, and S-O. Olofsson. 1988. Studies on the assembly of apo B-100-containing lipoproteins in HepG2 cells. J. Biol. Chem. 263: 4434-4442.

4. Borén, J., M. Wettesten, S. Rustaeus, M. Andersson, and S. O. Olofsson. 1993. The assembly and secretion of apoB-100-containing lipoproteins. Biochem. Soc. Trans. 21: 487-493.

5. Stillemark, P., J. Borén, M. Andersson, T. Larsson, S. Rustaeus, K-A. Karlsson, and S-O. Olofsson. 2000. The assembly and secretion of apolipoprotein-B48-containing very low density lipoproteins in McA-RH7777 cells. J. Biol. Chem. 275: 10506-10513.

6. Adiels, M., C. Packard, M. J. Caslake, P. Stewart, A. Soro, J. Westerbacka, B. Wennberg, S. O. Olofsson, M. R. Taskinen, and J. Borén. 2005. A new combined multicompartmental model for apolipoprotein B-100 and triglyceride metabolism in VLDL subfractions. J. Lipid Res. 46: 58-67.

7. Boström, P., L. Andersson, M. Rutberg, J. Perman, U. Lidberg, B. R. Johansson, J. Fernandez-Rodriguez, J. Ericson, T. Nilsson, and J. Borén, et al. 2007. SNARE proteins mediate fusion between cytosolic lipid droplets and are implicated in insulin sensitivity. Nat. Cell Biol. 9: 1286-1293.

8. Boström, P., L. Andersson, B. Vind, L. Håversen, M. Rutberg, Y. Wickström, E. Larsson, P. A. Jansson, M. K. Svensson, R. Brånemark, et al. 2010. The SNARE protein SNAP23 and the SNARE-interacting protein Munc18c in human skeletal muscle are implicated in insulin resistance/type 2 diabetes. Diabetes. 59: 1870-1878. 